\title{
PENGARUH FRAKSI VOLUME SERAT TERHADAP KEKUATAN MEKANIK KOMPOSIT SERAT JERAMI PADI EPOXY DAN SERAT JERAMI PADI RESIN YUKALAC 157
}

\author{
Andi Saidah, Sri Endah Susilowati, Yos Nofendri \\ Program Studi Teknik Mesin,Fakultas Teknik, Universitas 17 Agustus 1945 Jakarta \\ Kampus Sunter Agung, Sunter Podomoro, Jakarta 14130. \\ E-mail : andisaidah@yahoo.co.id
}

\begin{abstract}
ABSTRAK
Penggunaan material logam untuk kebutuhan industri yang terbuat dari bahan logam mengakibatkan ketersediaan bahan baku logam di alam semakin menipis. Para peneliti terus berupaya untuk mendapatkan solusi terbaik dalam menemukan bahan alternatif pengganti logam . Sebagai bahan pengganti logam, material tersebut harus memiliki beberapa kelebihan yang tidak dimiliki oleh bahan logam, antara lain sifat mekanik yang baik, tahan korosi, bahan baku mudah didapat dari alam dan memiliki sifat ramah lingkungan. Salah satu bahan yang sesuai dengan kriteria di atas adalah bahan komposit [1].

Penelitian ini dilakukan menggunakan metode proses Handlay up dengan cara menata serat secara teratur tanpa celah, setelah selesai diatur kemudian resin dituang kedalam cetakan. Objek penelitian berupa serat jerami padi yang berkualitas dan dipilih yang berserat panjang,dan sebagai bahan matriks dipilih resin resin epoxy dan Resin Yukalac 157. Spesimen komposit dibuat dengan menggunakan standar ASTM D 3039/D , dan standar ASTM D $256-03[6]$.

Dari hasil penelitian komposit berpenguat serat jerami padi - resin epoxy dan resin yukalac157 menunjukkan bahwa penambahan serat akan mengakibatkan peningkatan harga kekuatan impact, dan kekuatan tarik pada material komposit. Harga kekuatan tarik, dan kekuatan impact tertinggi terjadi pada specimen dengan fraksi volume serat 30\%, dan matrik resin epoxy 70\% yaitu masing-masing 14,75 MPa untuk uji tarik , 23,52 MPa untuk uji impak, dan untuk resin yukalac157 yaitu 5,88 MPa untuk uji tarik, dan7,58 MPa uji impak. Dan untuk uji SEM terjadi void yang berdiameter rata-rata 5,228 $\mu \mathrm{m}$.
\end{abstract}

Kata Kunci : Serat Jerami -epoxy, serat jerami -resin yukalac, uji tarik,dan uji impak.

\section{PENDAhuluan}

Saat ini perkembangan ilmu pengetahuan dan teknologi terus berkembang disemua bidang, seperti bidang kontruksi kendaraan, kontruksi bangunan, industri, dan juga bidang rekayasa material khususnya komposit. Perkembangan tersebut tidak terlepas dari semakin meningkatnya kebutuhan dan kelangkaan material yang tersedia di alam. Pengunaan material untuk industri masih banyak mengandalkan bahan logam yang tidak dapat diperbarui. Oleh karena itu dibutuhkan material pengganti yang dapat diperbarui, serta memiliki sifatsifat mekanis yang dapat mengimbangi keunggulan bahan logam. [1-4],

Komposit memiliki sifat-sifat unggul seperti ringan, kuat, tahan terhadap korosi, dan bahan bakunya tersedia dalam jumlah banyak. serat yang digunakan pada material komposit terbagi menjadi dua, yaitu serat alam dan serat sintetik. Serat sintetik dibuat di industri dengan dimensi tertentu dan homogen seperti serat gelas, gravit, dan kevlar. Sedangkan serat alam merupakan serat yang dihasilkan dari hewan, tumbuhan, dan proses geologis [5-7].

Pada saat ini komposit dengan bahan penguat serat sintetis telah digunakan dalam berbagai aspek kehidupan, baik dari segi penggunaan, maupun teknologinya. Penggunaannya tidak terbatas pada bidang otomotif saja, namun sekarang sudah merambah ke bidang-bidang lain seperti rumah tangga dan industri. Namun, penggunaan serat sintetis sebagai penguat komposit memiliki dampak negatif pada lingkungan karena limbahnya tidak dapat terurai secara alami dan dapat mengganggu hingga beberapa generasi. Penggunaan serat alami sebagai penguat komposit merupakan langkah bijak, mengingat untuk serat alami dapat terurai secara alami, dan banyak ragam serat alami yang tersedia misalnya serat goni, serat nanas, serat ijuk, serat sabut kelapa, dan lain-lain[8-10].

Bahan komposit pada umumnya terdiri dari dua unsur, yaitu serat (fiber) sebagai bahan penguat dan resin sebagai bahan pengikat serat. Dari campuran tersebut akan dihasilkan material komposit yang mempunyai sifat mekanik dan karakteristik yang berbeda dari material pembentuknya.

Dalam perkembanganya, serat yang digunakan tidak hanya serat sintetis (fiberglass) tetapi juga serat alami (natural fiber). Komposit serat alam memilki keunggulan lain bila dibandingkan dengan serat gelas, komposit serat alam sekarang banyak digunakan karena jumlahnya banyak, lebih ramah lingkungan karena mampu 
terdegradasi secara alami, harganya pun lebih murah dibandingkan serat gelas. Kelemahan serat alami di antaranya ukuran serat yang tidak seragam usia serat sangat mempengaruhi kekuatannya. Semakin kecil diameter serat maka kekuatan tariknya besar, karena rongga pada serat kecil dan ikatan antar molekulnya banyak sehingga kekuatannya kuat. Semakin besar diameternya, maka kekuatan tariknya kecil, karena rongga pada serat besar dan ikatan molekulnya sedikit, sehingga kekuatan tariknya rendah (Munandar, 2013). Pengembangan serat alami sebagai penguat material komposit ini sangat baik mengingat ketersediaan bahan baku serat alami di Indonesia cukup melimpah. [5-7].

Beberapa faktor yang mempengaruhi performa Fiber-Matriks Composite antara lain:

- Jenis serat, serat digunakan untuk dapat memperbaiki sifat dan strukur matrik, mampu

- menjadi bahan penguat matrik pada komposit untuk menahan gaya yang terjadi.

- Orientasi serat, menentukan kekuatan mekanik komposit yang mempengaruhi kinerja komposit tersebut.

- Panjang serat, sangat berpengaruh terhadap kekuatan dimana serat panjang lebih kuat

- dibandingkan serat pendek.

- Bentuk serat, pada umumnya semakin kecil diameter serat akan menghasilkan kekuatan komposit yang semakin tinggi.

- Jenis matrik, matrik berfungsi sebagai pengikat serat menjadi sebuah unit struktur, melindungi dari perusakan eksternal, meneruskan atau memindahkan beban eksternal pada bidang geser antara serat dan matrik.

- Ikatan serat-matrik, keberadaan void dalam komposit akan mengurangi kekuatan komposit yang disebabkan ikatan interfacial antara matrik dan serat yang kurang besar.

- Katalis, digunakan untuk membantu proses pengeringan resin dan serat dalam komposit[8-13].

\section{Komponen Penyusun Komposit}

Matriks dalam struktur komposit bisa berasal dari bahan polimer, logam, maupun keramik. Matriks secara umum berfungsi untuk mengikat serat menjadi satu struktur komposit. Filler (pengisi) adalah bahan pengisi yang digunakan dalam pembuatan komposit, biasanya berupa serat atau serbuk. Serat yang sering digunakan dalam pembuatan komposit antara lain serat E-Glass, Boron, Carbon,Epoxy dan lain sebagainya. Bisa juga menggunakan serat alam antara lain serat kenaf, pisang, jute, rami, cantula dan lain sebagainya. [2$6]$.

\section{METODE PENELITIAN}

Bahan yang digunakan dalam penelitian ini terdiri dari serat jerami padi, resin epoxy dan hardener. ASTM D3039 untuk uji tarik, dan ASTM D 256 - 03 untuk uji impak . Pembuatan specimen menggunakan metode Handlay up yaitu Proses ini dilakukan dalam kondisi dingin dan dengan memanfaatkan keterampilan tangan. Serat bahan komposit ditata sedemikian rupa mengikuti bentuk cetakan, kemudian dituangkan resin sebagai pengikat antara satu lapisan serat dengan lapisan yang lain. Demikian seterusnya, sehingga sesuai dengan ukuran dan bentuk yang telah ditentukan[1] .Uji specimen dilakukan untuk mengetahui perubahan sifat mekanis bahan dilakukan uji tarik,dan uji impak. Kemudian dilakukan foto stuktur makro terhadap jenis perpatahan yang terjadi pada spesimen setelah pengujian. [5-9].

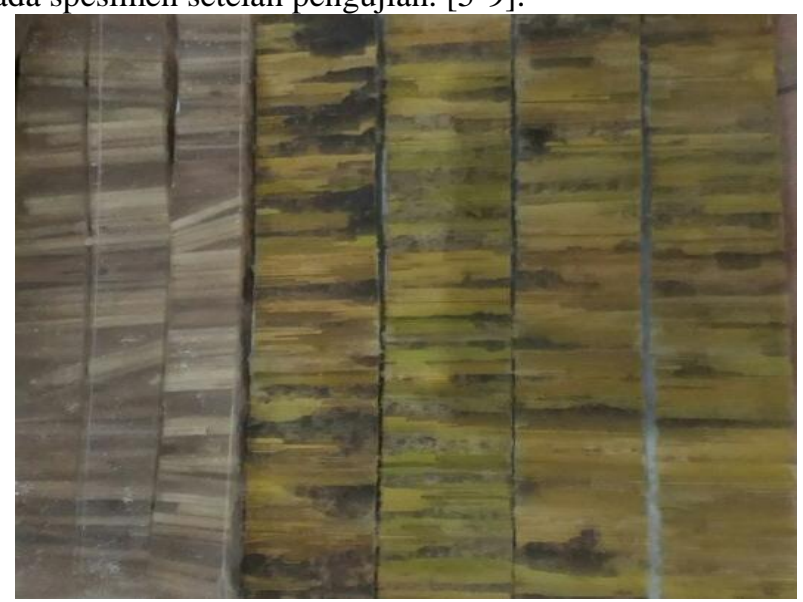

Gambar 1. Material komposit serat jerami padi

\section{HASIL DAN PEMBAHASAN}

Kekuatan tarik menunjukkan kemampuan untuk menerima beban atau tegangan tanpa menyebabkan komposit menjadi rusak atau putus. Ini dinyatakan dengan tegangan maksimal sebelum putus yaitu ultimate 
tensile strength (UTS). Adapun dalam penelitian ini diperoleh data kekuatan tarik yang berkisar antara 2,97 MPa- 14,75 MPa.(2)

Pengujian kekuatan tarik dan uji impak dilakukan dengan tujuan untuk mengetahui sifat-sifat mekanik suatu material seperti kekuatan tarik, tegangan luluh, dan regangan yang terjadi, dan untuk mengetahui seberapa besar pengaruh fraksi volume dan orientasi serat terhadap kekuatan tarik specimen, dan Kekuatan Tarik (tensile strength) menunjukkan kemampuan bahan untuk menerima beban / tegangan saat rusak / patah untuk komposit, dinyatakan dengan kemampuan maksimum sebelum putus. Hasil pengujian tarik dan impak dengan material serat jerami padi resin yukalac dan resin epoxy ditunjukkan didalam tabel 1.

Table 1. Tegangan tarik komposit serat jerami padi yukalac, dan komposit serat jerami padi-epoxy tanpa penambahan $\mathrm{NaOH}$, dan dengan $\mathrm{NaOH}$

\begin{tabular}{|l|l|l|l|l|l|l|l|c|}
\hline $\begin{array}{l}\text { Komposisi } \\
\text { serat }\end{array}$ & \multicolumn{4}{|c|}{ Tegangan tarik (MPa) } & \multicolumn{4}{c|}{ Tegangan impak (Joule) } \\
\hline & \multicolumn{2}{|c|}{ Tanpa NaOH } & \multicolumn{2}{|c|}{ Dengan NaOH } & \multicolumn{2}{c|}{ Tanpa NaOH } & \multicolumn{2}{c|}{ Dengan NaOH } \\
\hline & JP-Ply & JP- Epx & JP-PLy & JP- Epx & JP- PLy & JP-Epx & JP-PLy & JP- Epx \\
\hline $10 \%$ & 2,97 & 6,43 & 3,87 & 6,99 & 3,06 & 8,51 & 3,56 & 4,23 \\
\hline $20 \%$ & 3,33 & 8,89 & 3,53 & 10,69 & 4,34 & 12,16 & 5,24 & 12,12 \\
\hline $30 \%$ & 4,78 & 14,295 & 5,88 & 14,75 & 6,78 & 18,08 & 7,58 & 23,52 \\
\hline $40 \%$ & 3,25 & 5,55 & 4,55 & 8,54 & 3,59 & 4,22 & 4,79 & 10,85 \\
\hline
\end{tabular}

Ket: $\mathrm{JP}=$ jerami padi , Yk = Yukalac, Epx $=$ Epoxy

Dari tabel 1. Terlihat bahwa kekuatan tarik komposit menurun seiring dengan penambahan jumlah fraksi volume serat jerami. Penurunan kekuatan itu disebabkan oleh ikatan yang kurang baik antara serat jerami padi dengan matrik resin epoxy dan resin yukalac. Ikatan yang tidak baik ini disebabkan adanya kandungan wax dan silika dalam serat yang menghalangi pembentukan ikatan antara serat dengan matrik, selain itu juga disebabkan karena jerami padi tingkat penyerapan nya kurang sehingga timbul void yang mengakibatkan ikatan antara serat dan resin tidak terjadi dengan sempurna. Sebagaimana diketahui bahwa batang padi/jerami mengandung wax dan silika yang cukup tinggi (3.7\% dan 9-14\%, Mantanis $\mathrm{dkk}$, 2002). Penambahan jumlah batang padi/jerami juga mengakibatkan penurunan kekuatan tarik dan impak dari komposit serat jerami padi yukalac.

Kekuatan tarik komposit menurun seiring dengan pertambahan fraksi berat serat jerami padi, namun nilai kekuatan tariknya masih sesuai dengan standard uji bumper otomotif. Dari data diatas terlihat bahwa komposit serat jerami padi masih layak digunakan sebagai material bumper otomotif.

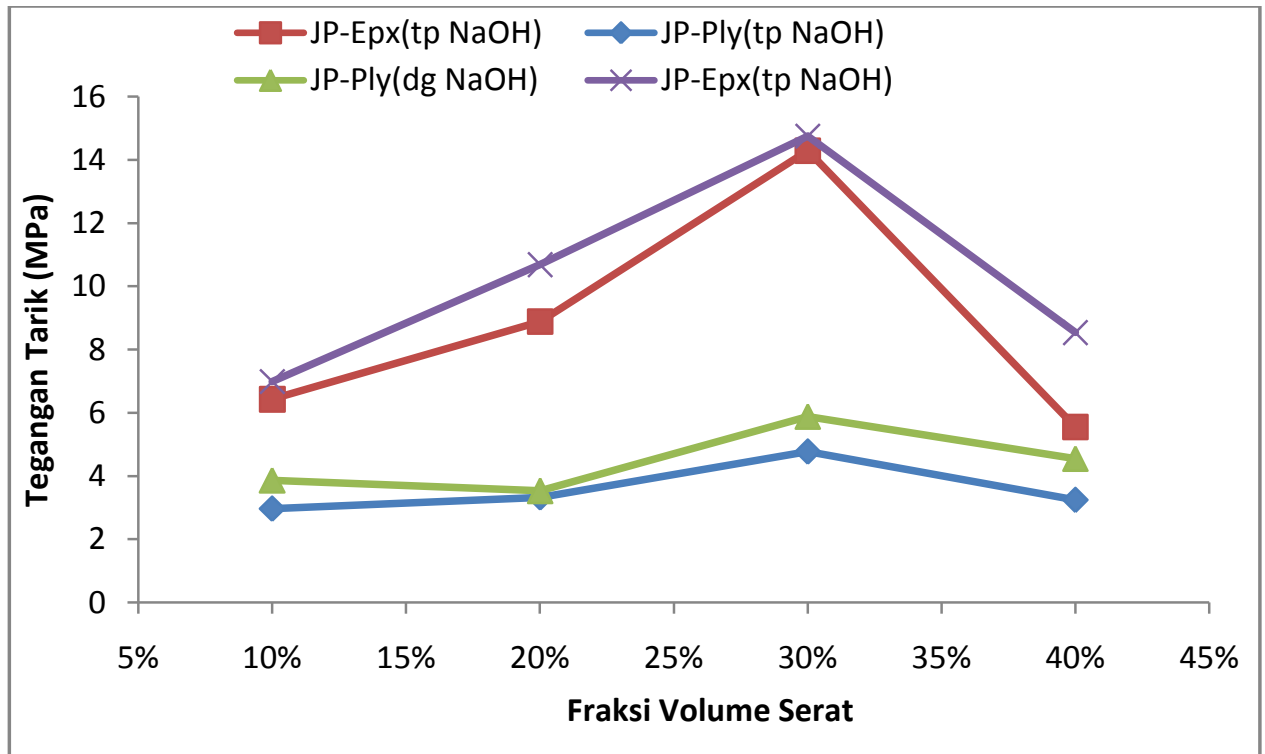

Gambar 2. Tegangan tarik komposit serat jerami padi yukalac, dan komposit serat jerami padi epoxy tanpa $\mathrm{NaOH}$, dan dengan $\mathrm{NaOH}$ 


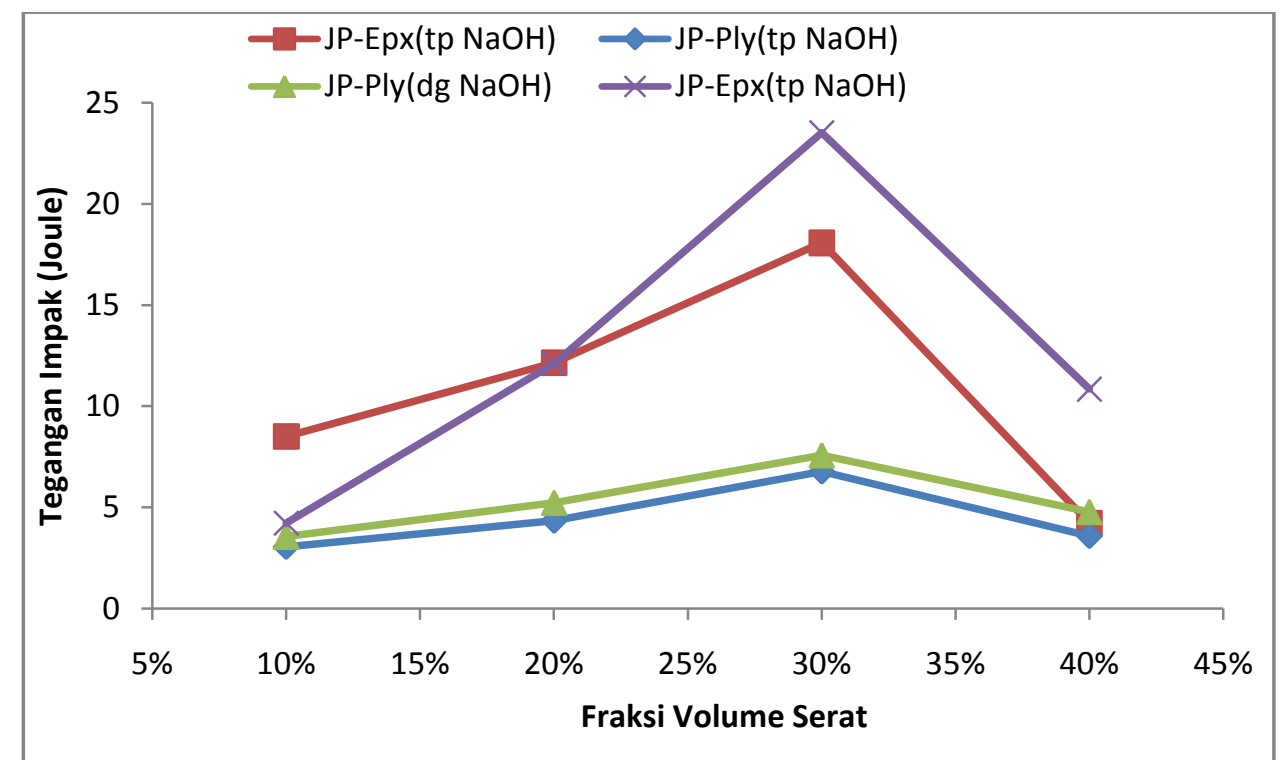

Gambar 3. Tegangan impak komposit serat jerami padi resin yukalac, dan komposit serat jerami padi-resin epoxy tanpa penambahan $\mathrm{NaOH}$ dan dengan $\mathrm{NaOH}$

Dari gambar 1 dan 2, diperoleh hasil bahwa pada fraksi volume penguat 30\% serat jerami padi epoxy diperoleh komposit dengan kekuatan tarik tertinggi yaitu 14,75 MPa. Sedangkan kekuatan tarik komposit terendah pada fraksi volume penguat $10 \%$ serat jerami padi yukalac sebesar 2,97 MPa. trend kekuatan tarik komposit dengan volume penguat jerami padi yang diperoleh mengalami kenaikan, kemudian pada fraksi volume serat $40 \%$ mengalami penurunan.

Void atau gelembung udara merupakan akibat yang tidak bisa dihindari pada saat proses pembuatan. Untuk itu sebisa mungkin meminimalkan void yang dihasilkan pada bahan komposit. Voids (kekosongan) yang terjadi pada matrik sangatlah berbahaya, karena pada bagian tersebut penguat tidak didukung oleh matriks, sedangkan penguat selalu akan mentransfer tegangan ke matriks. Hal seperti ini menjadi penyebab munculnya crack, sehingga komposit akan gagal lebih awal. Kekuatan komposit terkait dengan void adalah berbanding terbalik yaitu semakin banyak void maka komposit semakin rapuh dan apabila sedikit void komposit semakin kuat. Void juga dapat mempengaruhi ikatan antara serat dan matrik, yaitu adanya celah pada serat atau bentuk serat yang kurang sempurna yang dapat menyebabkan matrik tidak akan mampu mengisi ruang kosong pada cetakan. Bila komposit tersebut menerima beban, maka daerah tegangan akan berpindah ke daerah void sehingga akan mengurangi kekuatan komposit tersebut. Pada pengujian tarik komposit akan berakibat lolosnya serat dari matrik. Hal ini disebabkan karena kekuatan atau ikatan interfacial antara matrik dan serat yang kurang besar (Schwartz, 1984)

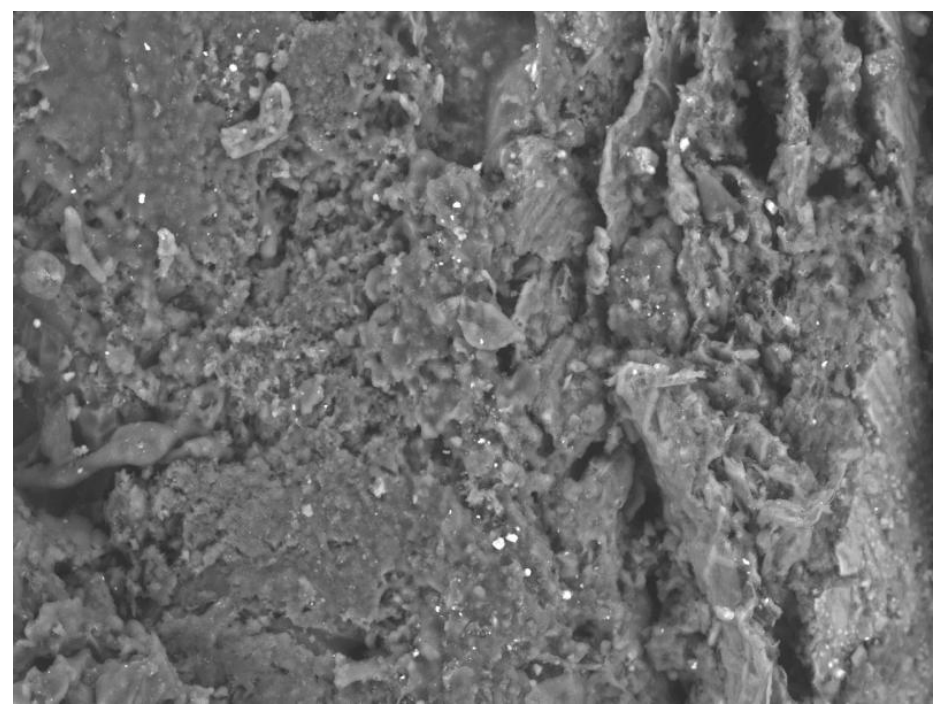

Gambar 4. Foto sem permukaan patah tarik pembesaran 500 um 


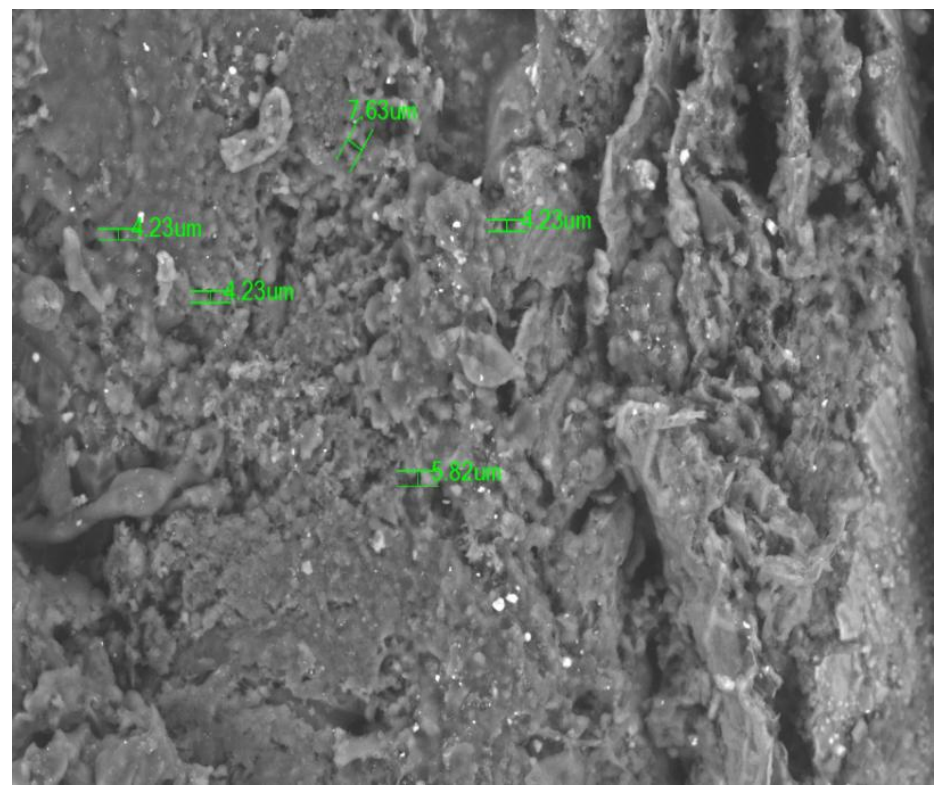

Gambar 5. Foto sem permukaan patah tarik pembesaran 500 um

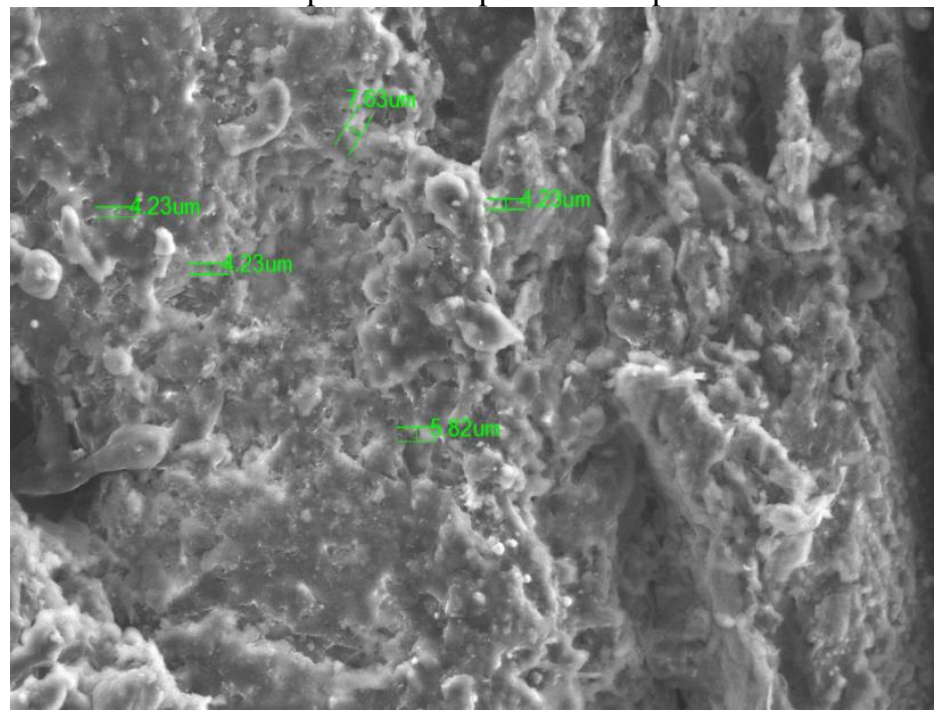

Gambar 6. Foto sem permukaan patah tarik pembesaran 500 um

Hasil pengamatan foto SEM dapat dilihat dari gambar 2, 3 , dan 4. Dari gambar tersebut terlihat bahwa semakin besar fraksi volume serat jerami padi, maka jumlah void yang terjadi semakin banyak. Peningkatan jumlah void ini disebabkan oleh adanya kerusakan pada ikatan antara serat dengan matriksnya, hal ini disebabkan daya ikat antara serat dengan matriks tidak sempurna, factor lain karena penambahan voleme fraksi serat dan orientasi sudut serat juga mempengaruhi kekuatan ikat antara serat dan matriks.

\section{KESIMPULAN}

Dari penelitian ini dapat diambil kesimpulan bahwa peningkatan fraksi volume serat jerami padi epoxy dan komposit serat jerami padi yukalac akan mempengaruhi kekuatan mekanik yukalac. Demikian pula dengan void yang terjadi itu tergantung dari ikatan antara serat dan matriks, jika ikatan yang terjadi sempurna, maka void nya kurang.

\section{DAFTAR PUSTAKA}

1. Applications" Proceedings of a seminar held by the food and agriculture organization of the UN (FAO) and the common fund for commodities (CFC), Rome, 13 December 2000.

2. Aladin Eko Purkuncoro, Basuki Widodo, Anang Subardi,2018," Penggunaan Fraksi Volume Komposit Serat Batang Pisang Kepok ( Musa Paradisiaca) Orientasi Sudut Acak Dengan Matrik Polyester Terhadap Sifat Mekanik", Jurnal Flywheel, Volume 9, Nomor 1, Februari 2018.

3. Alcides L. Leao, “Application of Natural Fibers In Automotive Industry In Brazil

4. ASTM,"Annual Book of ASTM Standards", Section 8: Plastic, Philadelphia USA, 2012. 
5. Budi Saroso, "Rami, Penghasil Bahan Tekstil, Pulp dan Pakan Ternak", Balai Penelitian Tembakau dan Tanaman Serat, Malang, AgrUMY Vol. VIII, 2000.

6. Daniel Andri Porwanto, Lizda Johar M ST.MT," Karakterisasi Komposit Berpenguat Serat Bambu dan Serat Gelas Sebagai Alternatif Bahan Alternatif Bahan Baku Industri”. Jurusan Teknik Fisika FTI ITS Surabaya.

7. Gupta, A. Kumar, A. Patnaik, and S. Biswas, "Effect of different parameters on mechanical and erosion wear behavior of bamboo ber reinforced epoxy composites," International Journal of Polymer Science, vol. 2011, Article ID 592906, 10 pages, 2011.

8. Hendri Hestiawan , Asrul Fauzi,2014," Studi Pengaruh Fraksi Volume dan Susunan Serat Terhadap Kekuatan Tarik dan Bending Komposit Resin Berpenguat Serat Rotan (Calamus Trachycoleus)", Jurnal Mechanical, Volume 5, Nomor 1.

9. Hindum Amalia, Sutikno,2014" Pengaruh Komposit Epoxy HGM pada Bumper Depan Kendaraan untuk Mereduksi Energi Impact.”Jurnal Fakultas Teknologi Industri Institut Teknologi Sepuluh Nopember (ITS).

10. Jyoti Prakash Dhal1 and S. C. Mishra2 "Processing and Properties of Natural Fiber-Reinforced Polymer Composite," Hindawi Publishing Corporation Journal of Materials Volume 2013, Article ID 297213, 6 pages, 2013.

11. Muhamad Muhajir, Muhammad Alfian Mizar, Dwi Agus Sudjimat," Analisis Kekuatan Tarik Bahan Komposit Matriks Resin Berpenguat Serat Alam Dengan Berbagai Varian Tata Letak", Jurnal Teknik Mesin, No. 2, Oktober 2016

12. Papan Partikel Jerami Padi Mechanical and physical properties of particle board rice straw. Jurnal Fakultas Kehutanan Universitas Tanjungpura.

13. Paryanto Dwi Setyawan*, Nasmi Herlina Sari*, Dewa Gede Pertama Putra”, Pengaruh orientasi dan Fraksi Volume Serat Daun Nanas (Ananas Comosus) terhadap Kekuatan Tarik Komposit Poliester Tak Jenuh(UP)". Dinamika Teknik Mesin, Volume 2 No.1, Januari 2012

14. Pramuko Ilmu Purboputro, Agus Hariyanto,2017”, Analisa Sifat Tarik dan Impak Komposit Serat Rami dengan Perlakuan Alkali dalam waktu 2,4,6, dan 8 jam bermatrik Poliester”. Media Mesin: Jurnal Ilmiah Teknik Mesin Vol. 18 No. 2 Juli 2017: 64-75.

15. Rahman, Junaidi. 2002. Pemanfaatan Limbah Gergajian Kayu Pinus Sebagai Bahan

16. Ulrich Riedel,"High Performance Applications of Plant Fibers in Aerospace and Related Industries",German Aerospace Center (DLR), Germany, 1999.

17. Wijang Wisnu Raharjo, Dody Ariawan,2008", Pengaruh Pemakaian Serbuk Jerami IR64 Sebagai Filler Komposit UPRs Terhadap Kekuatan Tarik Di tinjau dari Variasi Fraksi Berat.”. Jurnal Mekanika, Vol 7 Nomor 1, September 2008.

18. SAE, "SAE Handbook 1995", Volume II, Society of Automotive Engineers Inc, Warrendal, PA, 1995

19. S. Kalia, L. Avérous, J. Njuguna, A. Dufresne, and B. M. Cherian, "Natural fibers, bio- and nanocomposites," International Journal of Polymer Science, vol. 2011, Article ID 735932, 2 pages, 2011. 